\title{
The Body as Manifestation of Memory
}

\author{
Diego Salcedo Fidalgo
}

\begin{abstract}
The body understood as patrimony puts to test notions dealing with memory, representation and the body itself. All of them are concepts that articulate this research in order to think the place from where we look -art history and the museum as viewing mechanisms-. Also, we will examine how body expressions are understood and appropriated from an individual, collective and symbolic perspective. What concepts and understandings emerge from the relations between the body (contemporary dance approach), art history (paintings), the museum (as a viewing mechanism) and the notion of patrimony? And, in which sense they make us reflect on contemporary art practices that are concerned with body matters, space, experience and society?
\end{abstract}

Index Terms-Art piece, body, dance, memory, museum.

\section{INTRODUCTION}

My own approach to the subject of "cartographies of the body" is an attempt to reopen discussions related with the way art history has been practiced and written in the western tradition. In his book Art History after Modernism (2003), Belting Hans, incites to review the traditional discourses and approaches typical of western thoughts about art history. According to him, they impede us from looking at, for example, the reaction on this tradition from the artistic contemporary practice.

These "new" endeavors to exercise and write art history inevitably have to recognize and review contemporary art manifestations; therefore this exploration begins with an encounter with the La La La human Steps ${ }^{1}$ contemporary dance group from Canada, whose artistic proposal articulates paintings, different visual languages and, of course, dancing. Three paintings made by the Spanish painter Diego Velázquez, La Venus del espejo, Las Hilanderas y Las Meninas, are the starting point for this group to experiment with art history, Cinema and concepts about the museum.

Constant reinventions of body language against classic ballet structures, as well as the choreographic coalitions between painting, music and media stimulate the redefinition lordly discourses dealing with cultural production and art history. What exactly makes Velázquez paintings able to constantly reinvent themselves? How can we

Manuscript received June 8, 2013; revised August 6, 2013.

Diego Salcedo Fidalgo is with the Universidad de Bogotá Jorge Tadeo Lozano, Colombia (e-mail: diego.salcedof@utadeo.edu.co).

${ }^{1}$ La La La Human Steps was born in 1980 after a series of spectacles presented, during three weeks, in the little theater of l'Eskabel in the StHerni neighborhood, in Montreal. From that day, the group became one of the best-known dance companies, due to their choreographic language as well for their constant reinvention of their practice. understand and write the petite histoire ${ }^{2}$ through contemporary dance? What are the consequences of these kinds of proposals on art history discourses?

The body considered from the images' "heritage" 3 demands the examination of concepts like memory and representation, which at the same time articulate this analysis in order to think the place from where we look art history and the museum as viewing mechanisms. Also, we will examine how artistic and plastic body expressions are understood and appropriated from an individual, collective and symbolic perspective. In Le petit musée de Velázquez, [1] the La La La Human Steps dance group (the dancers), the choreographer Édouard Lock and the cinematographer Bernar Hébert, combine efforts to make possible a reinterpretation of Velázquez paintings through the body's potentials and movements, introducing the spectator in new dimensions of perception and understandings. In the overture of the chapter "Art History as an Anachronic Discipline" [2], Georges Didi-Huberman states: "Always before image, we are before time", and inquiries "But, what kind of time, fractures, rhythms and strikes of time are we dealing with in this image aperture?"

Certainly one that someone's gaze experiences from the present reconfiguration of the past.

From this perspective, both the proposals made by the well-known Spanish painter and that of the Canadian dance company, explore the possibilities of a new formula concerned with a different view on works of art. In the same sense, new forms of practicing history can be transformed by particular appropriations of memory, through different fictions. Hence, image can be thought as an innovative construct of different media and time's options in order to question traditional models of the "Archaeology" of art history. Moreover, historic interpretation raises the chance of involving heterogeneous, discontinuous and transversal modes of time, leading "open" types of image to materialize.

The relation that Le petit musée de Velázquez has with concrete images resides on the way contemporary dance can work new concepts on history and time. The body, its image, becomes the vehicle through which the emitter ( $L a L a L a$ Human Steps dance group) and the receiver (the spectator) ${ }^{4}$ start to recognize and reconfigure some sort of smaller scale art history, one that is based on three Velázquez paintings. In Didi-Huberman's own words: "Before an image - as old as it may be - the present never stops reconfiguring itself even if the dismissal of one's gaze hasn't entirely gave way to the highbrow convention of the Specialist" [3]. In other

\footnotetext{
${ }^{2}$ The term petite histoire refers to La La La Human Steps proposal "Le petit Musée de Velázquez" and to the limits imposed from the history of art tradition to that topic.

${ }^{3}$ The images" "heritage" alludes to memory of cultural representation of the body and its treatment in history.

${ }^{4}$ The notions of emitter and receiver don't imply a linear look, but turn out to be necessary in order to explain perceptive senses in this context.
} 
words, the possibilities of being questioned by an image, like those presented in Le petit musée de Velázquez's miseen-scène, are built by means of "free" reconfigurations.

As quoted by Joanne Entwistle, the British anthropologist Mary Douglas asserts: "There is a natural tendency among all societies to represent the body, because the body itself and its physiological characteristics, as well as its residual products, can nourish culture with a rich foundation for symbolic work" [4]. In consequence, the body's pictorial image transmits information about certain cultural situations and, in this case, the body itself turns into a symbol of that situation. From this perspective Velázquez paintings suggest new ways of seeing the world during the Spanish Golden Age. The artist surpasses the academic conventions of his time and confronts painting by using new perceptive treatments of the body, that is to say, an idealized and policed body in terms of ecclesiastic power. It is from Velázquez's review and handling of the Renaissance that the La La La Human Steps group embodies the paintings through movement and dance; in this sense they intervene in its form and alter the representation. We are in front of a new interpretation that translates painting into movement. Dance reestablishes time and space through an oneiric trail, where new codes of sensation and perception are introduced, where reality and fiction are intertwined into a new experience for the spectator, one that has to do with the body beyond language and representation. The dancer's body is not only the place from where we experiment the world of the painting, but also is through their mediation that we actually enter to the pictorial image. Hence, the outcome of the La La La Human Steps proposal is euchronically [5] analogous to Velázquez innovative perspective, in relation to the constructions of the image. The euchronical sense is the revolutionary atemporality of the two approaches. This is a term used by Georges DidiHuberman.

It is this last element that drives my research, since it permits the encounter of two different artistic media, painting and dancing, that collide and give birth to a fiction; becoming also the space where the collection, the reminiscing and the production of art takes place: The museum.

\section{The Museum Space In The ReinVention of The ARTWORK: LAS HILANDERAS}

On the one hand the museum is the symbolic place where an artwork stands and represents the living remnants of an artist, situating him/her in relation to the practice of painting in the course of an era. On the other hand it is the place where reception and exhibition of art history happens, where the spectator expects to find what cannot be discovered in books.

One good example of this instance is the View of Delft, by Johannes Vermeer, that elucidates the meaning of memory in the context of paintings. In the same way that Velázquez's experiences connect with Lock's Choreography in Le petit musée de Velázquez, Marcel Proust introduces in his work the life of Vermeer, his past and present synchronically conjugated. Svetlana Alpers, in the chapter "The View from the Studio", assures that the phenomenon of memory, and its relationships with other practices as literature, does not pretend to illustrate rather than to instigate discovering new outcomes. It also introduces us to the work of Proust in Le temps retrouvé and recalls the chapter where this phenomenon is visible: "Proust writes about Bergotte's death right after looking at the painting in the exhibition. Before him, the reconstruction of the past, that Proust's writing establishes, seems to be surpassed by the present" [6].

In the same sense, Las Hilanderas, in terms of memory, represents the hybrid character of the artwork in action and the multiple possibilities that artistic media can find in the act of remembering. They take us through the domains that creativity circumscribes in the relation between images of the past, right when the cultural and artistic traditions are redefined in the present. Hence, Velázquez generates through his ingenious creations a constant reconfiguration of what is far and what is close, while time and space represent a fractal of history in his works, See the analysis that Svetlana Alpers develops in the chapter "singularidad del arte" from the book Por la fuerza del arte, Velázquez y otros (2008).

Las Hilanderas embodies that indetermination of space and time, and puts to test something devious for the art historian: The imperious task of finding the terms that designated an artwork in its own time and how its reception was. Furthermore, Las Hilanderas makes a statement about the sources of its own creation; the fact that it has been written very little about this piece charges it with speculations and interpretations, and since it has been copied and imitated in very few cases there is a lot to assimilate and reinterpret in a creative and theoretical sense.

Up to this point it is important to mention Alpers' hypothesis about the value of the artistic work, of the collection and the idea of an imaginary museum. The piece she refers to tells the story of Minerva and Arachne, not in terms of moralistic fables about pride, but as a reification of the artistic work. According to Alpers, it is not entirely about the partition between arts and crafts, as it is commonly taken, rather than conciliation between the artist and the media, the court and his own singularity. Singularity understood not in the sense of recognition or an artistic debt to a master, but in the sense of his own compromise as a painter. Thus Lock's approach is quite similar, since he is a well-known choreographer and, in his own words, his exploratory work has been "self-referential" [7].

Las Hilanderas represents the kind of labor where there's no loom but a specialized combination of tasks, including lacing and weaving. It resembles the spirit inherent in the creative field, the artist's studio and the museum, rather than a slight look at the decorative tapestry belonging to the King.

Moreover, La La La Human Steps plays with the same imaginary place, with that contemporary dance studio, which is memory's scenery. Since dance does not necessarily hold a foundational genealogy, it seems to be lacking of memory and has to turn to other approaches of manufacturing history. Consequently, it is Velázquez's illusionist magic to disregard painting, as well as it is Lock's one to re-signify and mix music with painting. The new setting that Las Hilanderas finds in his play defines a 
new topography, relating two media in a new "multidirectional geography, a mobile net of sensorial connections that draws a new passage of intensities"[8]. Through Las Bailarinas and not Las Hilanderas, Lock permits the invention of a whole new piece, the one of a dancer inventing him or herself while dancing, manufacturing him/her own materiality, one that extends to the spectator, the same that Velázquez creates by reflecting on his own painting.

So forth we have comprehended how contemporary dance seeks for the enrichment of perception by using the faculties of physical presence. In the case of Lock's Las Hilanderas, rock music and body performance are conjured as conditions for a spectator to have conscience of how perception works, which is the heart of fiction. We can actually say that in Velázquez painting we see more a fantasy rather than a woman's work reality, "The illusionist magic of disregarding the paint" [9]. Velázquez museum is indeed the painter's museum, it is his studio and also the place where imagination resides and, according to Alpers, a place of "a collection of expansive sense: a proliferation of copies, evocations, imitations and, certainly, rivalries" [10].

\section{Venus at Her Mirror, The Status of The Feminine BODY}

With this painting, Velázquez stands in the borders of the Italian Renaissance tradition of the nude, avoided and despised by the Spanish artistic spheres. Once he proposes a new way of seeing the body, he manages to supplant religious motifs in painting for the new pictorial possibilities offered by other themes, either mythological or human. This way of seeing concedes a particular appeal to the feminine form that places Velázquez as "unique" inside the spheres of artistic production, as a painter in the court of Felipe IV.

The new formula gives Velázquez a fresh value among the artistic practice, one related with singularity, "not in the execution of human liberty, but as resistance to coercion". Svetlana Alpers develops a thesis about the sense of singularity in Velázquez that shows his independence from other artist of his time. It is also an alternative to the view of Velázquez as a court painter.

[11]. According to Svetlana Alpers, Velázquez craving in the court of Felipe IV was to conciliate his artistic brilliance with social ambitions, since the competition between artists manifested a breaking point with, what Alpers identifies as, a culture of singularity and envy [12]. Right when he provides painting with the new form of feminine nude, he places it in relation to the exuberant women painted by Tiziano and Rubens, and at the same time innovates by representing the first thorough nude; resembling more the image of an ordinary human being rather than a goddess. Beyond representation, Velázquez sought to dislocate painting's traditional gaze, particularly on the nude. He also confronted Spanish painting by playing with profundity, by setting certain objects and bodies at variable distances, by placing the sheets, the mirror, Venus' body, cupid's and certain other bodies in relation to a transversal curtain and a wall on the background. All of these elements give us the idea of a very large dwelling. Therefore, it is curious to observe the reflection of the image on the mirror, which is very blurry and builds a baroque contradiction since Venus is the goddess of beauty and her face cannot be seen clearly. This is the manner that Velázquez uses to reify the artist work in questioning the lifeless traditional values of painting, most of all practiced by the power of the Church ${ }^{5}$.

Moreover the Spanish painter offers a theoretical plan that has a fundamental impact over the body's image in light of his own artistic context. "The naked body is not only, not anymore, a privileged carriage of the truth or even the expression of passions; it is the basis, the measure and the model for the unity of representation as a whole" [13]. Far from rousing devotion, La Venus del espejo provokes a certain effect that deviates the image from its traditional task. Because the dissemination of prints and, consequently, the circulation of mythological images (in which the presence of erotic nudity was evident) were enormous during the XVII century in Europe, an erotized gaze was well spread from the Renaissance outside the traditional circles of art consumption. About this matter Jean Luc Nancy states: "Velázquez has not left the body naked, he has invented it, and he is nudity himself" [14]. In this case, Venus' naked body lets the spectator see her uncovered and vulnerable back, in this way "de-erotizing" female nudity and turning it closer to reality. What we see is the reflection of an ordinary woman and not of a goddess who donates an identity to the naked body. In this order of ideas, the Spanish painter conciliates a tradition of catholic values with new possibilities for the practice of painting, all in his permanent urge to resist coercion.

It is clear, by now, that the "revolutionary" elements in Velázquez painting are closely associated with the remarkable formulas of production and creation used by the La La La Human Steps group. In fact, this dance company assimilates the eclectic and hybrid forms present in the paintings by developing certain kind performatic gesticulations. This mediation leads to explorations and interpretations of the contemporary world where the body "decolonizes" the relation between the choreography and the dancer. Eduard Lock's work speaks from the anxieties of contemporary bodies, which extend from feminist issues, Queer issues, to Postcolonial Critique (the construction of identity), as far as it breaks up with western traditional body aesthetics. Le petit musée de Velázquez turns into a response to generic conventions of representation, of movement, of the body.

Thus, in La Venus del espejo, the dancers turn into plural bodies and the androgynous bodies predominate, for instance Louise Lecavalier ${ }^{6}$ embodies a tough and developed musculature to foster delicate gestures; so we are encountered by a reorganization of genre, not only in terms of painting but in terms of feminine identity.

In Velázquez painting, Venus founds herself in the company of Cupid who holds a mirror in front of her as an invitation for the spectator to see the whole piece and at the

\footnotetext{
${ }^{5}$ The power of the Church refers to the other painters who did not have that "singularity" and the position of Diego Velázquez in the court of Felipe IV.

${ }^{6}$ Louise Lecavalier is an internationally known dancer, also known for being the muse of Édouard Lock. She has contributed with a particular body language to the La La La Human Steps group.
} 
same time to see him reflected on her. Employing an analogous formula the dancers use gesticulation to dislocate time and space, turning them into body and movement which, at the same time, suggest an approach to performance dance; in this sense, they permit the existence of multiple non normative bodies, those bodies that threaten traditional trails where bodies occur.

The La La La Human Steps group's innovative interpretation of feminine nudity, through Velázquez artworks, is indeed liberating in the sense that their performed bodies confront standards and offer alternatives, and different modes of perception, that suggest and push their physiognomy to its limits. Lock instigates the dancers to produce compulsive movements, to feel their pulses and to produce projections into the space (including movement, sound and image) that persuade gaze's transversal possibilities. At the same time he invites us to surrealistically wonder around Velázquez paintings, following its equilibrium points, its displacements and the bodies' suspension in time and space.

We have seen that Velázquez and his works represent a considerable turn in the process and actions of artists in time; they are symbols of a transformation where the artistic space is life itself, or to paraphrase Alpers, Velázquez does not make art out of life but takes life out of art.

When an artist disturbs the social hierarchies and the cultural processes involved in the paintings of an era, he/she seems to be projected beyond his/her immediate culture. Consequently, La La La Human Steps pursues an entrance to that obscure world inside Velázquez paintings and sets it as a principle of all corporeal and emotional mobility. Following Rilke's expression when he talked about poetry as the cross between forms and the imagination of them, that's exactly the place where Le petit musée de Velázquez stands [15].

In relation to this, Édouard Lock asserts:

"Nor the creators neither the interpreter have the possibility of deciding completely what the spectator is going to finally receive. Each time you conceive something interesting enough, it can mean a lot of things at the same time. [...] The complete comprehension of the body has disappeared from painting a long time ago. Instead, in dancing, we saw a form of art that deals with tangible things, with the real body, therefore abstraction seems impossible, because we are made out of real blood and flesh. However, it is true that abstraction is indeed possible and I'm not implying anything new at all. What really counts are the perceptions of these tangible elements that we put on stage. And if I move my hand really fast, the hand turns transparent and formless, in this sense the body that moves is abstract" [16].

\section{CONCLUSION}

Through this analysis we have seen how the change of meaning in art has several repercussions in the discourses of art history, becoming the scenery for artistic identity contradictions. In Belting's words, when it loses its "authority" and turns out to be "omnipresent and malleable", it starts to demand the act of writing to open a horizon, one that permits a comprehensive guide to a more permeable and welcoming image.

That kind of writing can be accomplished through the practice of contemporary dance, through the reinvention of the artworks that erects the traditions of history of art, as Velázquez's paintings do. New possibilities in understanding images can be centered in movement and gestures, reconfiguring from the present an image of the past. In Nietzsche's words, concerning carnival dances, in "the living images" each body can be successively the artist, the artwork, the spectator and the listener.

\section{REFERENCES}

[1] É. Lock, Le Petit MusÉE de VelÁZquez, 1994.

[2] G. D. Huberman, Ante el Tiempo, 2nd ed., Buenos Aires, Argentina: Adriana Hidalgo Editora S. A, 2006, pp. 31.

[3] G. D. Huberman, Ante el Tiempo, 2nd ed., Buenos Aires, Argentina: Adriana Hidalgo Editora S.A, 2006, pp. 32.

[4] J. Entwistle, El Cuerpo y la Moda, Una VisiÓN SociolÓGica, 1st ed., Barcelona, Spain: Paidos, 2002, ch. 1, pp. 17.

[5] G. D. Huberman, Op. Cit., pp. 36.

[6] S. Alpers, Por la fuerza del arte, Velázquez y otros, 2nd ed., Madrid, Spain: Centro de Estudios Europa Hispánica, 2008, ch. 1, pp. 37.

[7] M. D. L. Flors, "Entrevista - Édouard Locke: Deshacer las figuras para que el espectador las rehaga," En Moviment Reflexions Entorn de la Danza, no. 3, pp. 50, season 2008/2009.

[8] A. C. Albright, Choreographing Difference, 1st ed., Middletown, CT: Weasleyan University Press, 1997, ch. 2, pp. 30-32.

[9] S. Alpers, Por la Fuerza del Arte, Velázquez y Otros, 2nd ed., Madrid, Spain: Centro de Estudios Europa Hispánica, 2008, pp.198.

[10] S. Alpers, Por la Fuerza del Arte, Velázquez y Otros, 2nd ed., Madrid, Spain: Centro de Estudios Europa Hispánica, 2008, pp. 199.

[11] S. Alpers, Por la Fuerza del Arte, Velázquez y Otros, 2nd ed., Madrid, Spain: Centro de Estudios Europa Hispánica, 2008, pp. 146.

[12] S. Alpers, Por la Fuerza del Arte, Velázquez y Otros, 2nd ed., Madrid, Spain: Centro de Estudios Europa Hispánica, 2008, pp. 145-146.

[13] D. Arasse, "La carne, la gracia, lo sublime," in Historia del Cuerpo, 1st ed., vol. 1, A. Corbine, JJ. Courtine and G. Vigarello, Eds., Madrid, Spain: Santillana, 2005, ch. 10, pp. 413.

[14] D. Arasse, "La carne, la gracia, lo sublime" in Historia del Cuerpo, 1st ed., vol. 1, A. Corbine, J. J. Courtine and G. Vigarello, Eds., Madrid, Spain: Santillana, 2005, ch. 10R. Rilke, Sonetos a Orfeo, 1st ed., Santiago, Chile: Editorial Universitaria, 2002, pp. 55.

[15] M. D. L. Flors, "Entrevista - Édouard Locke: Deshacer las figuras para que el espectador las rehaga," En Moviment Reflexions Entorn de la Danza, no. 3, pp. 50, season 2008/2009.

[16] F. Nietzsche, Fragmentos póStumos, 1869-1874, 2nd ed., Madrid, Spain: Technos, 2007, vol. 1, pp. 70.



Diego Salcedo Fidalgo was born in 1972 . He is a Colombian art historian and consultant with an M.A. in museology from the University of Valladolid, Spain (2002) and a B.A. in history of art and film studies from the University of Montreal, Canada (1997). His primary fields of study are critical museology, and modern and latinamerican art.

He has been a professor at the Universidad de Bogotá Jorge Tadeo Lozano (UJTL) for a decade, primarily lecturing about modern art, notions on historiography of art and circuits, instutions and globalization of art. From 1998 to 2001, he performed as a consultant for the Educational and Cultural Division of the Museo Nacional de Colombia in Bogotá. His publications include titles such as "Reflexión y aplicación de la práctica curatorial, nuevos modos de exhibición y circuitos alternativos" in Spanish journal Museo y Territorio (ISSN:1888-4393) and "Restableciendo el poder femenino" in Colombian journal of psychoanalysis Divaneando (ISSN: 2322-7451). While his current research interests focus on subjectivities in art history through the work of Colombian painter Lorenzo Jaramillo, he has approached other topics including cartographies of the body and critical museology.

Mr. Salcedo works as a member of the publications committee of the Humanities Department at the Universidad de Bogotá Jorge Tadeo Lozano since 2009. 